\title{
Management Innovation Companies Based Business Cost Indicators
}

\author{
Nikolay Kuznetsov ${ }^{1}$ \\ ${ }^{1}$ University of Applied Sciences, Riga, Latvia \\ Correspondence: Nikolay Kuznetsov, University of Applied Sciences, Moscow, 107014, 4th Sokolnicheskaya, 3 , \\ build. 82. Russia. Tel: 79-26-780-4374. E-mail: nkuznetsov@outlook.com
}

Received: May 23, 2013 Accepted: July 28, 2014 Online Published: August 20, 2014

doi:10.5539/ass.v10n17p101 URL: http://dx.doi.org/10.5539/ass.v10n17p101

\begin{abstract}
The article highlights the features of management innovation companies based business cost indicators. The estimation of the value of business cost indicators constituting the three approaches, namely, market, cost and income. The necessity to use the highly-qualified labour resources, the last scientific inventions and researches, as well as the newest innovation technologies is emphasized. The innovation model of development should be used at the enterprise for this purpose. For the effective management of innovation companies it is necessary to control the situation on the market and execute management on the basis of indicators of the business cost. The management of the innovation companies on the basis of the business cost includes: management of the organizational capital, management of the intellectual capital, and management of information capital. As a result, the innovation company receives the wide client base, competitive prices, the high level of service, the high quality of the offered innovation services, the availability of the own innovation developments and highly-skilled staff.
\end{abstract}

Keywords: innovation, business, finance, management, business value, the income approach, the market approach, cost approach, intangible assets

\section{Introduction}

In modern conditions, a number of leading companies found themselves in a difficult financial situation. The market dictates tough requirements that they must follow. And innovative companies which every year become more and more, are no exception, intense competition has no mercy to those who cannot keep their positions in the market of innovative services. In the direction of management of innovation companies with using the indicators of the business cost the scientists consider several structural blocks: 1) innovation development of economy. It is necessary to emphasize the works of Gridzhuk I. A. (2008) Innovation component of the stable developments of the regional economy and Drucker P. F. (1993) Innovations and entrepreneurship practice and principles; 2) the market position of the company and its money flows. The issues are considered in the works of Galasyuk V.V. (200) About necessity of the usage of the concept "conditional money flow", Ievleva N.V. (2013) The influence on the investment activity of the industrial enterprise on the business cost, Kosorukova I.V. (2013) The profit and money flows in the estimation of the business cost, Minaeva O.A. (2013) The market position of the enterprise as a key factor of the business cost; 3) management of the company cost and business planning. We should note the works of Staryuk P.Y. The management of the company cost as the basic corporate management (2014), V.M. Popov (2012) Business planning, Karpenko A.V. (2014) The management of the business unit cost in the system of corporate management, Kornilov D.A. (2014) The dynamics of the corporation cost as an indicator of the stable business development (based upon PJSC "Gazprom"), Petrova A.I. (2013) The strategy of management on the basis of the real business cost, and others; 4) the evaluation of the enterprise (business) cost. This structural unit is mostly studied by the scientists. We'll emphasize some of them: Busov V.S. (2012)The evaluation of the enterprise (business) cost, Kostyurko R.A. (2008) The complex evaluation of the enterprise cost, Copeland T. (1999) The cost of companies: evaluation and management, Cahill M. (2012) The Financial Times Guide to Making the Right Investment Decisions, Nikitin S.A. (2014) The financial indicators, intangible assets and business cost, Razmakhova A.V. (2013) The cost as the most important evaluation indicator of the business effectiveness development, Kholodkova V.V. (2014) The practice of evaluation of the business cost at the entrance for IPO.

Purpose of this article is to highlight the features of management innovation companies based business cost indicators. 


\section{Statement of the Materials and Results}

These days, sustained economic development is not determined by the availability of raw materials or markets, but the possibility for companies to join the market of highly skilled labor, scientific inventions and new technologies, which is impossible without the formation of an innovative model of development and corporate social responsibility, working in the chain "formation - research and development - the production of goods and services - business ethics - the modern market" (Damodaran, 2004). P. Drucker, one of the first who described the value of the business as a worthy goal for the company, especially considering that it has to create value for customers, employees (especially manual workers) and distribution partners. Proceeding from the goals, management is focused on goal-setting and decision-making instruments to help managers at all levels in the creation of business value. However, he was skeptical about the fact that the dynamics of the business value can be formalized, at least, the existing methods (Porter, 1989).

Porter has defined the following components of the value chain of innovation: shareholder value, customer value, staff qualifications, partnerships, management, information technology, the strategy of creating business value and social value. In our opinion, the value of business innovation is influenced by other factors, such as environmental business, the quality of the created innovative product, the value of assets on the market, the overall situation in the market and industry, the macroeconomic situation in the country, etc.

Shareholder value is a part of capitalization of the innovative enterprise. It is true, as opposed to long-term debt. Such things as dividends, increase shareholder value and facilitate the issuance of shares of its financial condition. For a private company, the value of the company will be determined when the debt will be evaluated using one of several methods of valuation, discounted cash flows or other (Sliger, 2008).

Customer value of goods is determined by comparing it with other similar products and on the same grounds. This component of the strategy of an innovative company helps retain loyal customers and increase their number.

Personnel qualifications is determined by such factors as structure, level of education, efficiency, business qualities and organizational culture.

Partnership (Channel Partner Value) is determined by partnerships in business between consumers and companies as well as government institutions and non-governmental organizations. The role of partnerships can be critical to the functioning of innovative companies. They cease to exist or carry on business if a partnership is lost or broken.

Governance requires effective management, human-oriented principle, compliance with the approved system of values and value principles (Sward, 2006).

Building strategies of business value reflect the increase or decrease in the value of the company, which is traditionally measured by the degree of customer satisfaction, increase revenue, profitability, market share occupied, etc.

Information technologies (Business Value) affect the value of the business in terms of the formation of an enterprise architecture, business architecture, the process of design, and indicators information database, advertising, strategic management, etc. (Porter, 1989).

Social significance is a combination of economic efficiency and social performance through leveraging and optimizing the economic mechanisms of social institutions, matching interests and goals in the process of interacting economic activity subjects.

The components of the business, that are to be managed, and the factors influence on them are shown in Fig. 1.

The generalized method of business valuation that are designed in domestic and foreign scientific sources are expensive, and profitable market.

Speaking about the relative (market approach), it suggests that the value of equity innovative company valued at the amount for which it can be sold at a sufficiently mature markets (Damodaran, 2004).

In other words, the most probable price of a business can be a real selling price of similar businesses, fixed by the market.

The income approach is used primarily to evaluate businesses, industrial complexes and other business facilities. Due to the fact that the concept of income is associated with a specific production or provision of services, it is not very effective in the evaluation of certain types of work equipment (The income...). 


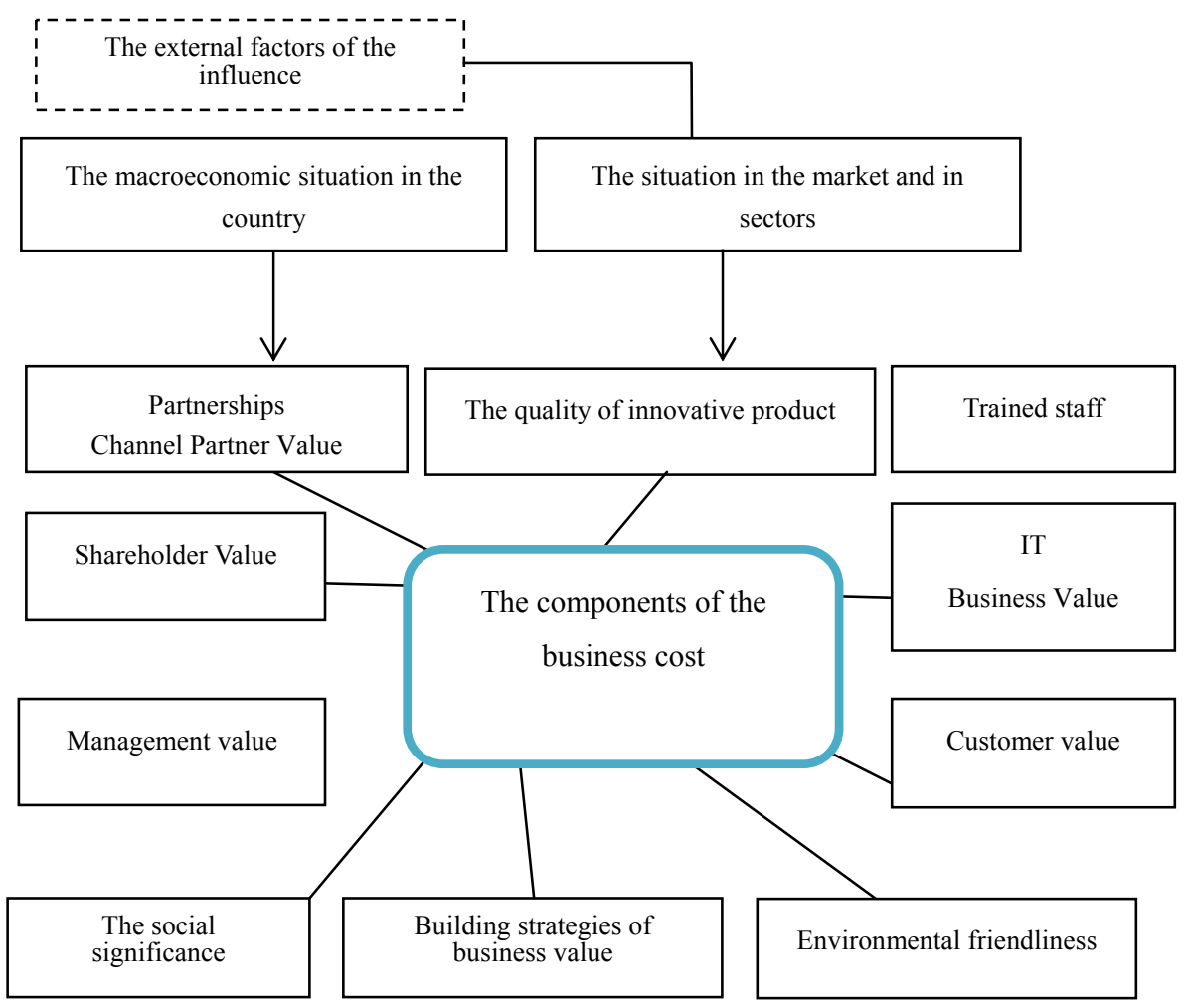

Figure 1. The components of the business value and impact factors *

\section{* - Constructed by the author}

Relatively costly, or property, business valuation approach, it should be noted that it is mainly used in the companies that own all kinds of assets, including financial, or when the business does not bring a stable income. Therefore, it is sometimes referred to as the valuation of underlying assets (asset valuations). It is elementwise assessment of the market value of assets and liabilities and is due to differences between the results of the book and market values of assets and liabilities of the components of (Damodaran, 2004).

In our opinion, to use only one method of valuation is wrongly. To obtain representative values on the basis of a comprehensive assessment of all the proposed methods should be carries out, but with the priority use of one.

We present a comprehensive evaluation methods constituting the business value of innovative enterprises (Table 1).

Table 1. Methods for assessing components of the business value of innovative enterprises that are to be managed *

\begin{tabular}{|c|c|c|c|c|}
\hline № & The components of the cost of business & \multicolumn{3}{|c|}{ Assessment methods } \\
\hline 1 & The right to technological objects & Profitable & Market & Expenses \\
\hline 2 & The rights to the assets of engineering & Profitable & Market & Expenses \\
\hline 3 & The copyright of creative activity & Profitable & Market & Expenses \\
\hline 4 & The rights to the software data & Profitable & Market & Expenses \\
\hline 5 & The right to use spaces & Expenses & Market & Profitable \\
\hline 6 & The right to use the long-term financial investments & Expenses & Market & Profitable \\
\hline 7 & The right to use land & Expenses & Market & Profitable \\
\hline 8 & The right to use the basic tools & Profitable & Market & Expenses \\
\hline 9 & The right to use an unfinished building & Expenses & Market & Profitable \\
\hline 10 & The right to use other assets & Expenses & Market & Profitable \\
\hline
\end{tabular}


For innovative intellectual property rights of intangible assets evaluation should be primarily income method and adjusted in accordance with the market and the cost method using the following algorithm: first, the cost is determined by the revenue of the company, then the market on the basis of which the value is adjusted, and then the value of the expenditure:

$$
\mathrm{Jj}=\mathrm{Dj} \times \mathrm{Rj} \times \mathrm{Vj},
$$

where $\mathrm{Ji}$ - is the estimated value of the business; $\mathrm{Vi}$ - is the estimated value of the business in accordance with the cost method; $\mathrm{Ri}$ - is the market value of the business; $\mathrm{Ri}$ - is profitability.

If $\mathrm{Dj}<\mathrm{Rj}$ taken according to the assessed value of the market - $\mathrm{Ri}$. If $\mathrm{Dj}>\mathrm{Rj}$ received revenues estimated value $\mathrm{Dj}$.

Consumables method is also performs as the corrective factor in the valuation of businesses, in particular:

- When we received the corrected value $(\mathrm{Dj} \times \mathrm{Rj})$, if the condition $(\mathrm{Dj} \times \mathrm{Rj})<\mathrm{Vj}$, then accepted the estimated value of $\mathrm{Vj}$;

- When we received the corrected value $(\mathrm{Dj} x \mathrm{Rj})$, if the condition $(\mathrm{Dj} \times \mathrm{Rj})>\mathrm{Vj}$, then accepted the assessed value (Dj x Rj).

For a group of assets, property, organizational and economic rights, preference is given to the expenses method, adjusted in accordance with the profitable and market.

Accordingly, the market and profitable methods are also advocate the method of business valuation adjustments with the development of the market, if such evaluation is possible (Eq. 2):

$$
\mathrm{Ji}=\mathrm{Vi} \times \mathrm{Ri} \times \mathrm{Di},
$$

where $\mathrm{Ji}$ - is the estimated value of the business; $\mathrm{Vi}$ - is the estimated value of the business in accordance with the cost method; $\mathrm{Ri}$ - is the market value of the business; $\mathrm{Ri}$ - si profitability.

When $\mathrm{Vi}<\mathrm{Ri}$ is taken according to the assessed value of the market - Ri. When $\mathrm{Vi}>\mathrm{Ri}$ accepted expenditure assessed value - Vi.

On the basis of cost-based approach the management decisions are produced that affect the activities of innovative companies. In this innovative company management should be focused on the creation of a new product and promising environment for future income, including investments in intangible assets, increasing the company's market share.

Management innovation companies based business cost indicators. :

- management organizational capital, which will be focused on the adaptation to customer needs, matching its own corporate objectives, using leadership, team work and bonding. Well-built organizational structure allows you to do efficient management, which is essential;

- management of intellectual capital, which is focused on the level of innovation, competence and professionalism of the staff, their training and skills development. Intellectual capital enables you to select the workers who are endowed with sufficiently high intellectual qualities, and have the potential to learn and master new;

- management of information capital, which is directed to use the information and CRM-systems, customer database, which is a priority in the innovative management and administration in general. In addition to these components should also be added: Innovation Management (innovation, innovation, forecasting customer needs), production management (extension activities, focus on the experience of others and adapt solutions according to customer needs), and client management (relationship marketing and integrated focus on the client) (Fig. 2).

As a result, we will achieve the goals, namely: a broad customer base, competitive prices, high level of service; high quality of our innovative services and support relationships; having its own innovation and qualified personnel.

The detection of key factors of value - it is a creative process that has to operate by trial and error. Using only mechanical methods based on the available information, and purely financial approach rarely possible to establish key factors of the value. Linking the of value with business solutions allows you to create a "tree" of value, which is turns to making the right decisions. Thus, income from operations can be divided into segments by product type, geographic areas or categories of consumers. Cost factors cannot be considered in isolation from each other. For example, higher prices may itself significantly increase the cost, in a case if it will not lead to a significant loss of market share (Sward, 2006). 


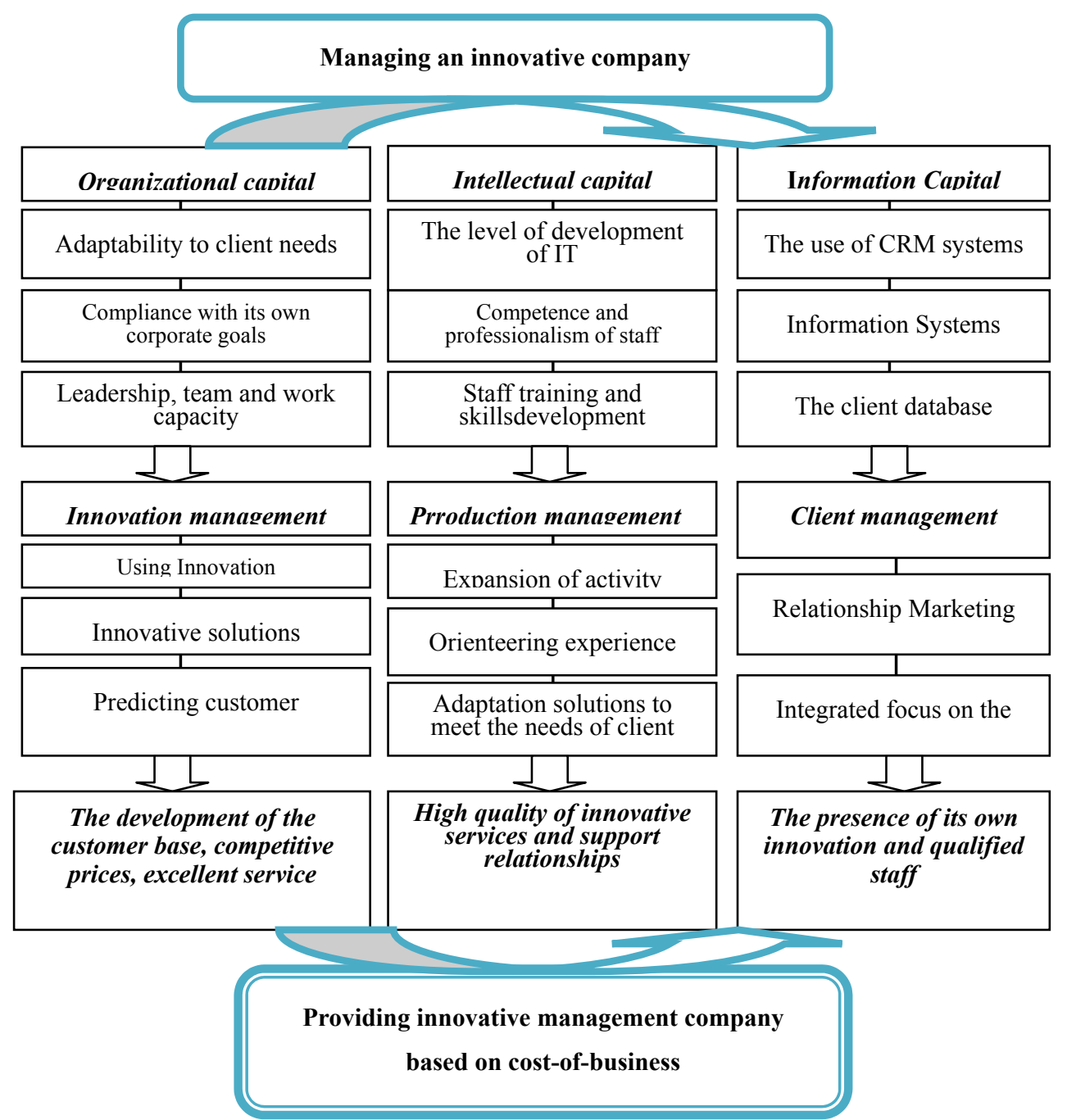

Figure 2. Model of innovative company *

* - Constructed by the author

In the management the value of the business is an unofficial term that encompasses all forms of value that determine the stability and prosperity of the company in the long term. Business value expands the concept of firm value beyond the economic value (also known as economic profit, economic value added and value of the shares) to other forms of value, such as the value of labor potential, customer value, the value of suppliers, channel partners, the value of cluster formations, management value and social value. Many of these forms of value are not directly measured in monetary terms.

Business value is often covers intangible assets that are not necessarily associated with any group of stakeholders, such as intellectual capital and the business model of the company. The Balanced Scorecard is one of the most popular methods for measuring and managing business value.

According to economic theory, the concept of business value provides an innovative company that it is best viewed as a network of relationships - both internal and external. These networks are sometimes referred to as value chains or value chains. Each node in the network can be a stakeholder group, the resource of the organization, end-users, stakeholders, regulators or the environment itself. In the network cost value creation is seen as a common, creative, synergistic process rather than the result of a purely mechanical or command control.

If an innovative company viewed as a network of value creation separate entities, the question arises: what is the contribution of each node in the network in the overall performance of the company? When the nodes are independent organizations (eg, suppliers) or agents (eg, customers), it is assumed that the company is committed 
to a cooperative, win-win relationship, where everyone plays a role. The elements in the process are not completely independent (for example, the workers). So, the other stimuli except for only direction financial compensations are required.

Although it is highly desirable to reduce all forms of business into one economic mechanism (such as discounted cash flow), many scholars and practitioners believe that this is not possible or practical, not theoretical. Thus, proponents of the value of business believe that the best approach is to measure and control the various forms of property, as they applied to each group of stakeholders. Presently there is no theory about how the different elements of the business cost are connected with each other. There is no theory about their influence on the long-term success of the company.

In this case, one of the most promising approaches is to build business models and cost management of innovative companies.

\section{Conclusions}

Management innovation companies based business cost indicators - is a very important strategic tool, especially in high-risk and poorly projected market situations, which helps the company avoid bankruptcy and take its rightful place in the market. It promotes continuous market monitoring and maintenance of effective competitiveness. The prospective direction of the further scientific studies should include the search of the priority factors, which affect the cost of the innovation business in the long-term prospect.

\section{References}

Boer, F. P. (2007). Valuation technology. Moscow: Olimp-Business.

Buditsky, A. E. (2007). Features of the market value of commercial bank. Finance and Credit, 30, 25-35.

Busov, V. I., Zemlyanskiy, O. A., \& Polyakov, A. P. (2012). VAN VI Evaluation of Enterprise. Moscow: Yurayt.

Cahill, M. (2012). Investment analysis and business valuation. Moscow: Business and Service.

Compilation of business plans with comments and recommendations. (2012). Moscow: Finances.

Copeland, T. (1999). Cost companies: Assessment and Management. Moscow: ZAO "Olympus-Business".

Ctaryuk, P. Y. (2013). Value-Based Management as the main task of corporate governance. Retrieved from http//www.cfin.ru

Damodaran, A. (2004). Investment Valuation. Tools and techniques of assessment of any assets. MA: Harvard Business Review.

Galasyuk, V. V. (2006). Need to use the concept of "conditional cash flow". Stock market, 18, 18-20.

Gutnick, E. V. (2008). Theoretical foundations of business valuation. Kramators'k: DSEA.

Hrydzhuk, I. A. (2008). Innovative element of sustainable economic development of the regions. Theory of micro-macroeconomics: Fri. scientific papers, 29, 239-240.

Ievleva, N. V., \& Nesterenko, T. V. (2013). The influence on the investment activity of the industrial enterprise on the business cost. The International scientific edition The Modern Fundamental and Applied Studies, $3(10), 86-88$.

Karpenko, A. V., \& Nikiforova, L. E. (2014). The management of the business unit cost in the system of corporate management. The Siberian Financial School, 2(103), 105-113.

Kholodkova, V. V. (2014). The practice of evaluation of the business cost at the entrance for IPO. Finance and Credit, 2, 20-24.

Kornilov, D. A. (2014). The dynamics of the corporation cost as an indicator of the stable business development (based upon PJSC "Gazprom"). The Economy in Industry, 1, 55-61.

Kosorukova, I. V., \&Prokimnov, N. N. (2013). The profit and money flows in the estimation of the business cost. The Russian Entrepreneurial Activity, 18(240), 53-60.

Kostyrko, R. A. (2008). Comprehensive evaluation of a company: Monograph. Kharkov: Factor.

McNeil, R. (2007). Marketing research in B2B. Donetsk: Balance Business Books.

Mendrul, A. G. (2002). Cost Management companies. Moscow: Finance.

Minaeva, O. A. (2013). The market position of the enterprise as a key factor of the business cost. The scientific-empirical journal The Economy of Success, 1-2, 16-20. 
Momot, T. V. (2007). Business Valuation: Modern Technology. Moscow: Factor.

Nikitin, S. A., \& Pavlenko, D. A. (2014). The financial indicators, intangible assets and business cost. The Scientific Notes of Young Researchers, 2, 46-51.

Petrenko, V. A. (2006). International practice of business valuation company. Kiev: ArtEK.

Petrova, A. I., Zarudnev, A. I. (2013). The strategy of management on the basis of the real business cost. The Modern Scientific Studies and Innovations, 3(23), 10.

Popov, V. M. (2012). Business planning: A textbook for high schools. Moscow: Finances and Statistics.

Porter, M. E. (1989). Globaler Wettbewerb. Stratigien der neuen Internationalisierung. Wiesbaden: Gabler. http://dx.doi.org/10.1007/978-3-322-91343-2

Razmakhova, A. V. (2013). The cost as the most important evaluation indicator of the business effectiveness development. The Theory and Practice of the Public Development, 12, 116.

Saryucheva, T. A., Radzhabov, Z. M., \& Filenko, D. G. (2013). Some peculiarities of application of the comparative approach at evaluation of the business cost. The defence of the complex of the scientific-technical progress of Russia, 1, 109-112.

Sliger, M. (2008). The Software Project Manager's Bridge to Agility. Addison: Wesley.

Smirnickii, G. B. (2013). Business Valuation: basics, tools, and practice. Kiev: Art Economii.

Sward, D. (2006). Measuring the Business Value of Information Technology. Moscow: Intell Press.

Tarumian, L. S. (2012). Evaluation system of key performance characteristics of the business processes. Yerevan.

The income approach. (2014). The use of the income approach in the evaluation of transport. Retrieved from http://www.lider-biysk.ru

\section{Copyrights}

Copyright for this article is retained by the author(s), with first publication rights granted to the journal.

This is an open-access article distributed under the terms and conditions of the Creative Commons Attribution license (http://creativecommons.org/licenses/by/3.0/). 